\title{
OECDpublishing
}

\section{WARS AND CONFLICTS IN THE SAHARA-SAHEL}

\section{WEST AFRICAN PAPERS}

September 2017 No. 10

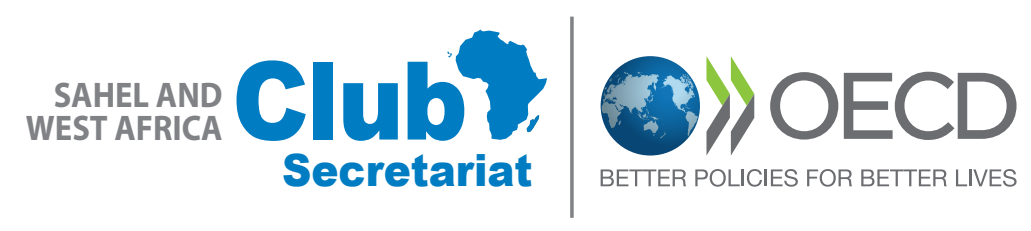





\section{WARS AND CONFLICTS \\ IN THE SAHARA-SAHEL}

This paper has been prepared by

OLIVIER J. WALTHER

Sahel Research Group, University of Florida 


\section{WEST AFRICAN PAPERS}

The West African Papers series explores African socio-economic, political and security dynamics from a regional and multidisciplinary perspective. It seeks to stimulate discussion and gather information to better anticipate the changes that will shape future policies. The series is designed for a wide audience of specialists, development practitioners, decision makers and the informed public. Papers are available in English and/or French, and summaries are available in both languages. Initiated by the Sahel and West Africa Club (SWAC) to highlight and promote West African issues, the work presented is prepared by its Secretariat, Members and partners, other OECD departments, related international organisations, associated experts and researchers.

For more information on the Sahel and West Africa Club: http://www.oecd.org/swac.

Please cite this publication as:

Walther, O. (2017), "Wars and conflicts in the Sahara-Sahel", West African Papers, N¹0, OECD Publishing, Paris.

https://doi.org/10.1787/8bbc5813-en

Author contact: owalther@ufl.edu

ISSN 2414-2026

OECD Working Papers should not be reported as representing the official views of the OECD or of its member countries. The opinions expressed and arguments employed are those of the authors.

This document and any map included herein are without prejudice to the status of or sovereignty over any territory, to the delimitation of international frontiers and boundaries and to the name of any territory, city or area.

Working Papers describe preliminary results or research in progress by the author(s) and are published to stimulate discussion on a broad range of issues on which the OECD works. Comments on Working Papers are welcomed, and may be sent to the Sahel and West Africa Club, OECD, 2 rue André-Pascal, 75775 Paris Cedex 16, France.

Authorised for publication by Laurent Bossard, Director, Sahel and West Africa Club Secretariat (SWAC/OECD).

You can copy, download or print OECD content for your own use, and you can include excerpts from OECD publications, databases and multimedia products in your own documents, presentations, blogs, websites and teaching materials, provided that suitable acknowledgment of OECD as source and copyright owner is given. All requests for commercial use and translation rights should be submitted to rights@oecd.org. 


\begin{abstract}
The Sahel and the Sahara are faced with exceptional political instability involving a combination of rebellions, jihadist insurgencies, coups d'état, protest movements and illegal trafficking. The backdrop to this accumulated violence is a globalised security environment, which blurs the traditional lines between what is local and global, military and civilian, domestic and international, politics and identity. The purpose of this paper is to analyse these patterns of violence. The first section presents the geographic distribution and development over time of the main sources of violence in North and West Africa before examining the events behind the increase in political violence in the Sahel and the Sahara. The second section analyses the patterns of violence, and focuses on the geographic scales thereof and the strategies of the warring parties. In its conclusion, the paper highlights the need to strengthen regional co-operation, restore the legitimacy of governments, and establish inclusive governance solutions in conflict zones.
\end{abstract}

Keywords: security, war, conflict, jihadism, terrorism, Sahara, Sahel JEL Classification: D74, F5, H56, N47

\begin{abstract}
ABOUT THE AUTHOR
Olivier J. Walther is Visiting Associate Professor in African Studies at the University of Florida and Associate Professor in Political Science at the University of Southern Denmark.

With a PhD in geography from the University of Lausanne, Dr. Walther has focused his research on the use of social network analysis to study trade, cross-border co-operation and terrorism in West Africa. His work has been funded by the European Commission, the World Food Programme, the OECD, the European Spatial Planning Observatory, the governments of Luxembourg and Denmark, and the Carlsberg Foundation. He is the Africa Editor of the Journal of Borderlands Studies and on the executive committee of the African Borderlands Research Network (ABORNE).
\end{abstract}

\title{
NOTE
}

This paper is an update of the chapter entitled "Security issues, movement and networks in the Sahara-Sahel" from An Atlas of the Sahara-Sahel published in 2014 by the OECD's Sahel and West Africa Club. Some parts of the present document are based on a blog written by the author and Antonin Tisseron in 2015, and reproduced here with the permission of The Broker: "Strange bedfellows: a network analysis of Mali's northern conflict". 


\section{ACRONYMS}

ACLED Armed Conflict Location \& Event Data Project

ADC May 23, 2006 Democratic Alliance for Change

AIS

AQIM

AND

ANR

ATNMC

CJA

CMFPR

CMA

CNR

CNRT

CNT

CPA

CRA

CSNPD

EUTM Mali

FARF

FARS

FDR

FIAA

FIS

FLAA

FLM

FNTR

FONALT

FPA

FPR

FPRN

FROLINAT National Liberation Front of Chad

FRRRT Force pour le ratissage, le regroupement et le redressement du Tchad

FUC United Front for Change

FUCD United Front for Democratic Change

GATIA Imghad and Allied Touareg Self Defence Movement

GCT Tunisian Combatant Group

GIA Armed Islamic Group

GICM Moroccan Islamic Combatant Group

GSL Free Salafist Group
GSPC Salafist Group for Preaching and Combat

HCUA High Council for the Unity of Azawad

ICJ International Court of Justice

IED Improvised explosive device

JEM Justice and Equality Movement

JNIM Jama'a Nusrat ul-Islam wa al-Muslimin'

LIDD Islamic League for Da'wa and Jihad

LIFG Libyan Islamic Fighting Group

LRA Lord's Resistance Army

MAA Arab Movement of Azawad

MDD Movement for Democracy and Development

MDJT Movement for Democracy and Justice in Chad

MIA Islamic Movement for Azawad

MINURSO United Nations Mission for the Referendum in Western Sahara

MINUSMA United Nations Multidimensional Integrated Stabilization Mission in Mali

MNJ Nigerien Movement for Justice

MNJTF Multinational Joint Task Force

MNLA National Movement for the Liberation of Azawad

MPA Mouvement populaire de l'Azawad

MPLA People's Movement for the Liberation of Azawad

MPS Patriotic Salvation Movement

MPSA Popular Movement for the Salvation of Azawad

MSA Mouvement pour le salut de l'Azawad

MUJAO Movement for Oneness and Jihad in West Africa

NTC National Transitional Council

POLISARIO Popular Front for the Liberation of Saguia el-Hamra and Río de Oro

PREGEC Food Crisis Prevention and Management

RAFD Rally of Democratic Forces

RDL Rally for Democracy and Liberty

RFUTD Rassemblement des fils unis du Tchad pour le développement

RPJ Popular Rally for Justice

SCUD Platform for Change, Unity and Democracy

SLA Sudan Liberation Army

UFDD Union of Forces for Democracy and Development

UFR Union of Resistance Forces

UNHCR United Nations High Commissioner for Refugees

UNESCO United Nations Educational, Scientific and Cultural Organization 


\section{TABLE OF CONTENTS}

EXECUTIVE SUMMARY.

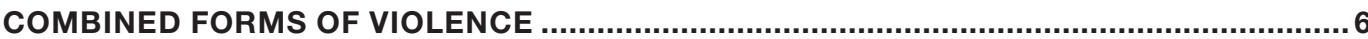

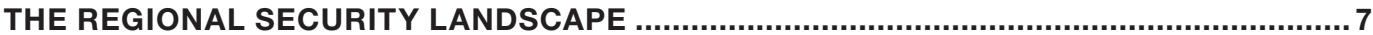

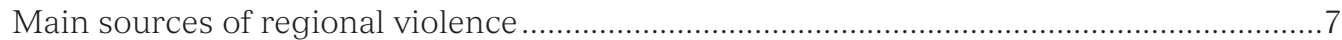

Growing political instability in the Sahara-Sahel ....................................................... 10

THE SPECIFICITIES OF WARS AND CONFLICTS

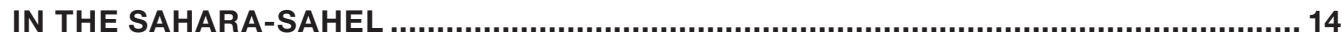

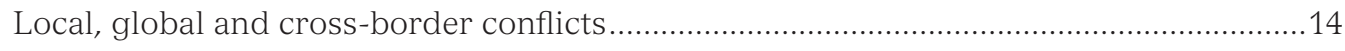

Widely varying alliances and rivalries ....................................................................... 16

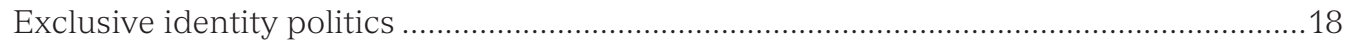

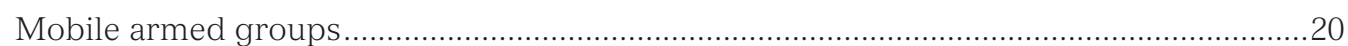

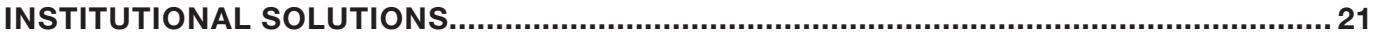

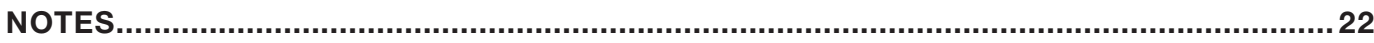

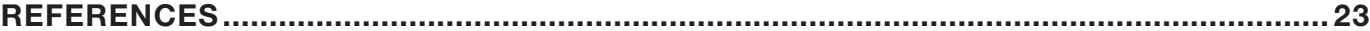

ANNEX: ARMED GROUPS IN OPEN CONFLICT WITH SAHEL-SAHARAN STATES, JANUARY 1990-DECEMBER 2016

\section{EXECUTIVE SUMMARY}

$\mathrm{T}$ his paper analyses the specificities of the security situation in the Sahel and the Sahara, which are faced with exceptional political instability involving a combination of rebellions, jihadist insurgencies, coups d'état, protest movements and illegal trafficking of drugs, weapons and migrants. The current backdrop to this accumulated violence is a globalised security environment, in which there are no longer clear boundaries between what is local and global, domestic and international, military and civilian, politics and identity.

Indeed, the particularity of these present day conflicts is that they use global resources to pursue local claims. The actors in Sahelo-Saharan conflicts use the permeability of national borders to relocate opportunistically depending on the military resources being deployed against them by the states in the region and their international partners. From a social perspective, the relationships between warring parties are marked by their extreme flexibility. Armed groups are splintered into factions which can temporarily join forces against a common enemy, and which reflect ethnic and socio-economic divisions. The lack of a far-reaching coalition of government forces, rebels or religious extremists is a factor which holds up peace processes, as evidenced in the conflict in Mali.

Many contemporary conflicts seem driven less by ideological considerations than by assertions of identity designed to promote an idealised vision of the past, such as the Caliphate. This political vision is based on using fear, hatred and destruction to create homogeneous ethnic or religious areas. One of the consequences of these identity politics is the killing and deliberate displacement of civilians, thereby marking a departure from earlier guerrilla warfare in which the aim was to win the hearts and minds of the local population. The military strategies and tactics used to achieve this objective revolve around great mobility and small numbers of fighters, whose attacks are designed not so much to defend territory as to control the population. 
The deterioration of the security situation over the last fifteen years demonstrates that military solutions must be found and applied on a regional basis. From this point of view, the Malian conflict was a catalyst for numerous regional initiatives designed to promote security, governance and development in the region. These "Sahel strategies" are now culminating in the creation by the G5 Sahel States of a joint military force. The newly created "Alliance for the Sahel" is expected to result in the co-ordination of the previously disparate initiatives by the region's principal donors.

At the same time, it also appears that long-term conflict resolution entails restoring the legitimacy of governments, which has been undermined "from below" by the proliferation of armed groups. The contradictory agendas and unpredictable alliances formed by these groups finish by blurring the customary distinction between government, the national army and society, which was previously one of the cornerstones of the modern states in the region. In recent decades, military interventions and international legal proceedings have also often superseded states "from above" when the latter have proved incapable of defending their territory, maintaining domestic order and protecting their cultural heritage. Lastly, the legitimacy of Sahel-Saharan states is subject to increased competition from non-governmental organisations whose actions, despite being driven by humanitarian reasons, elbow out public services, especially during conflicts.

Crisis resolution also requires finding inclusive governance solutions within each state. The fact that civilians pay such a high price in current conflicts should encourage the authorities to use the minimum necessary force in their anti-insurgency operations. A strategy aimed at protecting the civilian population from violence and gaining their support is the best way of countering the strategies of extremist groups based on fear and exclusion. This strategy can involve the creation of secure regions where alternative, more inclusive forms of policy are put in place, as well as the recognition of the virtues of diversity and cosmopolitanism, two vital ingredients in fighting identity politics.

\section{COMBINED FORMS OF VIOLENCE}

A period of severe political instability in the recent history of the Sahara and the Sahel began in 2003 when the Salafist Group for Preaching and Combat (GSPC) - later known as Al-Qaeda in the Islamic Maghreb (AQIM) - kidnapped some thirty Western tourists in the Algerian desert. From the Atlantic Ocean to Lake Chad, Senegal is the only country to still be left unscathed by armed conflicts or terrorism. This situation reflects differing dynamics of violence based on a mix of rebellions, jihadist insurgencies, bombings, hostage taking, coups d'état, protest movements from the Arab Spring, and the illegal trafficking of drugs, arms and migrants. When considered individually, none of these forms of violence are really new in the region. Rebellions have shaken the Sahara since the start of the colonial era, whereas there have been several waves of jihadism, which dates back even further, since the holy war led by Usman Dan Fodio in the north of what is now Nigeria in 1804. Coups d'état and political demonstrations are as old as the Sahel-Saharan states themselves, and trans-Saharan trafficking, including slaves, has defined the Sahara since medieval times.

So what are the specificities of the contemporary security situation? Is the Sahara-Sahel the victim of a simple escalation of the wars and conflicts ${ }^{1}$ which marked the region's $20^{\text {th }}$ century history, or has it become the location for armed struggles of a different kind? The aim of this paper is to help provide an answer to this question which is crucial not just for the stability of the Sahel-Saharan states but also for the safety of the civilian populations, who are the first victims of modern violence. Analysis of the social and spatial dynamics of conflicts reveals that the particularity of the current period is that it combines three types of organised violence in a globalised setting: armed struggles for political power, criminal activities for personal gain, and human rights violations to create homogeneous ethnic and religious areas. 
The recent history of sub-Saharan Africa since the end of the Cold War provides a dramatic illustration of this combined violence. The conflicts in the Great Lakes region, for example, were not just between states and their militias for control of the Burundi, the Democratic Republic of the Congo and Rwanda, but also involved criminal groups exploiting the mining and energy resources in Ituri and Kivu, and countless perpetrators of crimes against humanity, including those responsible for the Rwandan genocide. In addition, these conflicts brought to light the blurring of the boundaries between politics, economics and identity, with the same actors - including state representatives - capable of seeking power, personal gain and ethnic cleansing. Similar patterns have been seen in Liberia and Sierra Leone, where the violence organised by the state, criminal groups and identity entrepreneurs was particularly deadly in the 1990s. Over the past 15 years, the Sahel and the Sahara have hardly been spared either, especially in northern Mali, Liptako-Gourma, the Lake Chad region and Darfur.

The first section of this paper presents the geographic distribution and development over time of the main sources of violence in North and West Africa ${ }^{2}$. It then examines the events behind the increase in political violence in the Sahel and the Sahara. The second section analyses these patterns of violence by placing them in a context which goes beyond factual descriptions and the apparent unpredictability of the conflicts in the region. The final section of the paper provides several conclusions on public policy which underscore the need to put in place institutional solutions tailored to the new scales of, and combinations of actors in, Sahelo-Saharan conflicts.

\section{THE REGIONAL SECURITY LANDSCAPE}

$\mathrm{T}$ he violence witnessed in West and North Africa over the past 20 years has been concentrated in several flashpoints, related to the Sudanese and Nigerian insurgencies, and the civil wars and popular protests in Algeria, Egypt and Libya. The change in the security environment in the Sahara-Sahel since the 1960s reflects, for its part, the situation in Africa as a whole, characterised by an increase in conflicts involving non-state actors since the start of the 1990s (Melander et al., 2016).

\section{Main sources of regional violence}

The geographic distribution of the some 243000 civilian and military victims of violence in West and North Africa between 1997 and 2016, as reported in the Armed Conflict Location \& Event Data Project (ACLED) database (Raleigh et al., 2010; Raleigh and Dowd, 2015), is uneven. Political violence occurs in a restricted number of micro-regions rather than on nationwide scales.

- The main source of regional violence is in Sudan. Almost half of the victims in the region (109 160) died as a result of violence perpetrated by the Sudanese State, its allied militia and armed groups from Darfur in the east of the country, as well as the violence caused by the conflict in South Sudan, which bookended its accession to independence in 2011. In both the east and the south, there is a clear cross-border dimension, reflected in the mass exodus of refugees to neighbouring countries.

- The second source of regional conflict is in Nigeria. As of the decade which started in 2010, it has seen the outbreak of three forms of large-scale violence: the jihadist insurgency by Boko Haram ${ }^{3}$ in the cross-border region of Lake Chad, the acts of violence carried out by the armed groups in the Niger Delta against the federal government and the oil companies, and the ethnic tensions between pastoral herders and farmers in the Middle Belt. These three conflicts accounted for one-quarter of the civilian and military victims in the region between 1997 and 2016 (56 700 deaths). 
- The other epicentres of violence are located in the northern Sahara. In Libya, tensions following the fall of Colonel Gaddafi in 2011, as well as fighting between Islamic militias and pro-government forces during the civil war, have resulted in 15500 deaths over the period in question. In Algeria, most of the casualties are victims of the civil war which took place between the government and Islamist groups until the early 2000s (over 13000 deaths). In Egypt, most of the 10600 deaths resulted from the violence that followed the popular protests of the Arab Spring which started in 2011, and the crackdown by the military power on civil society and religious associations (in particular the Muslim Brotherhood).

Over the past 20 years, there have been significant temporal variations, with the exception of the Sudan region, which has been in almost constant conflict since 1955 (Map 1).

Map 1

The victims of violence in West and North Africa, 1997-2012
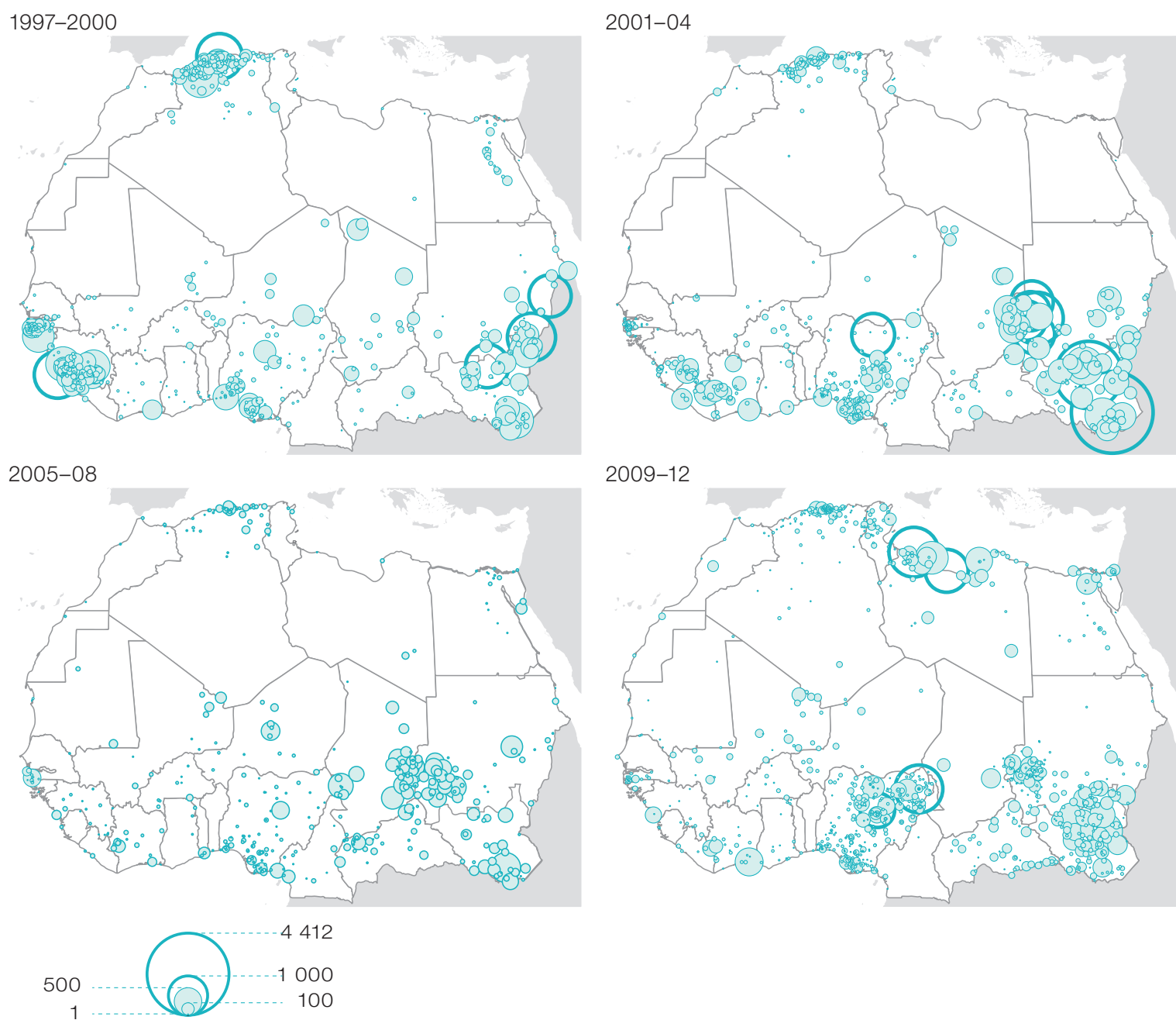

Source: ACLED, data 1997-2012 (www.acleddata.com/data/africa)

South of the Sahara, the high number of victims along the Gulf of Guinea in the late 1990s is attributable to the civil wars in Liberia (1989-97 and 1999-2003), Sierra Leone (1991-2002) and Guinea-Bissau (1998-99). Further deaths were caused by the fighting in the Algerian Civil War (1991-2002), which de-escalated significantly after the surrender of the Islamic Salvation Army (AIS) and the defeat of the Armed Islamic Group (GIA) at the start of the 2000s. Accordingly, the number of victims in Algeria fell from 3500 in 1997 to 130 in 2016 (Figure 1). 
Figure 1

Total number of victims of violence in West and North Africa, 1997-2016

Number of victims

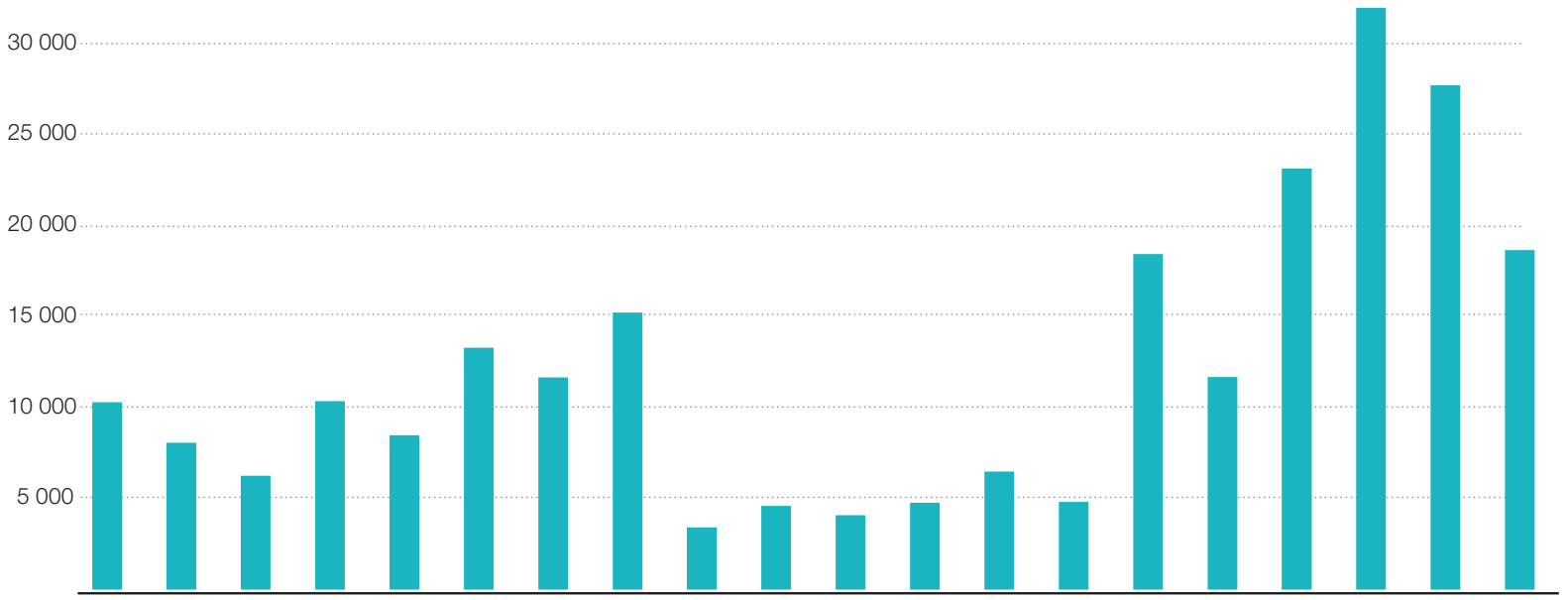

Source: ACLED, data 1997-2016 (www.acleddata.com/data/africa)

A return to political stability in Liberia and Sierra Leone at the start of the 2000s coincided with the start of the first civil war in Côte d'Ivoire (2002-07), and an increase as of 2003 in the intensity of the Darfur conflict between the Sudan Liberation Army (SLA) and the Justice and Equality Movement (JEM) on one side, and the Sudanese government and Janjaweed Arab militia on the other. The overall number of victims fell between 2005 and 2010, before rising significantly from 2012 onwards as a result of conflicts pitching rebels and religious extremists against governments in the region. The security situation reached its nadir in 2014 under the combined impact of the conflict in Mali which started in 2012, the civil wars in the Central African Republic and Libya, the conflicts in Darfur and South Sudan, and insurgencies in Nigeria (Map 2). The decline in the number of deaths noted as of 2015 is primarily due to Boko Haram losing ground around Lake Chad.

Map 2

The victims of violence in West and North Africa, 2013-16

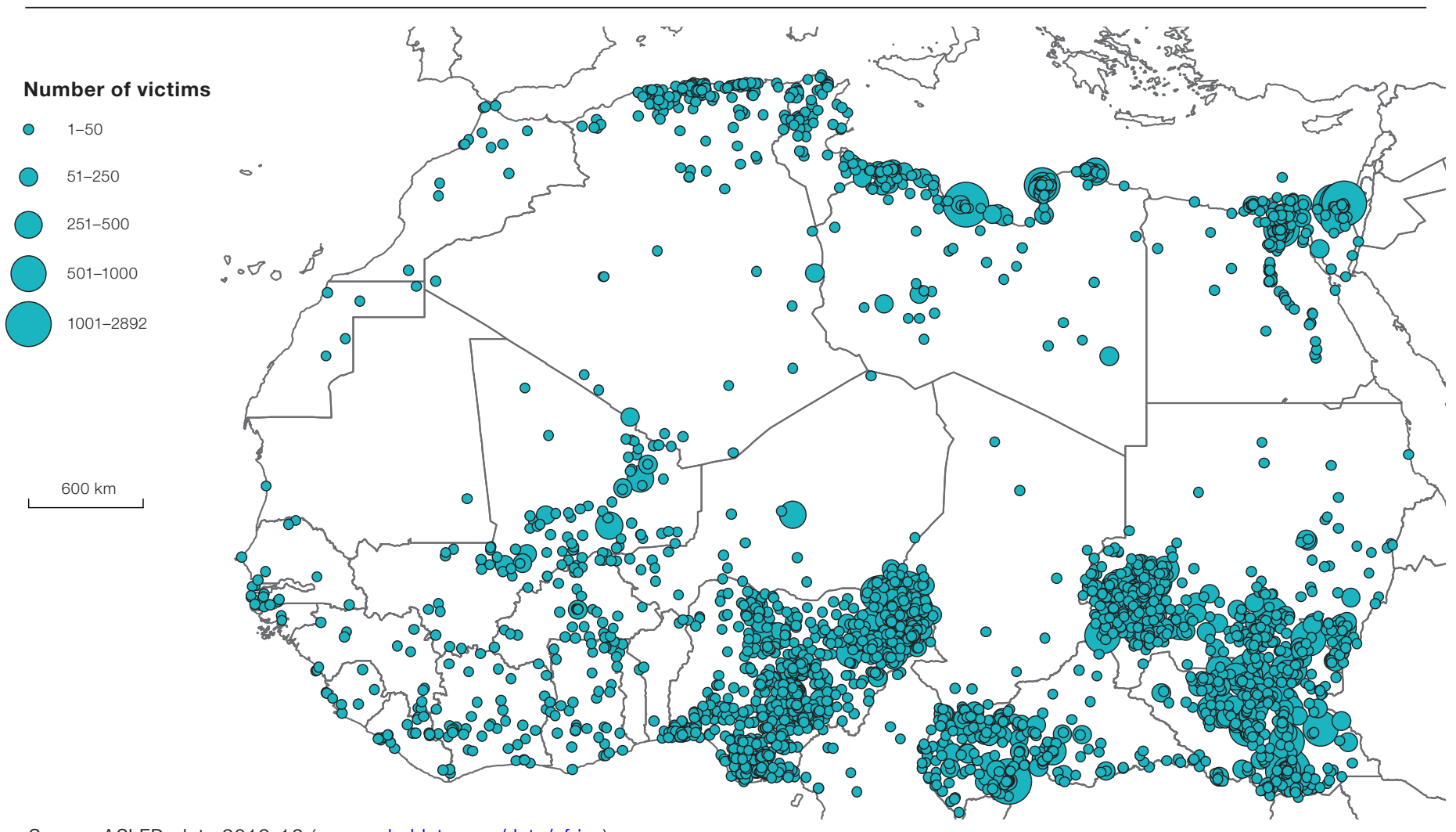

Source: ACLED, data 2013-16 (www.acleddata.com/data/africa) 


\section{Growing political instability in the Sahara-Sahel}

Over the course of the last fifty years, there have been several cycles of violence in the Sahara-Sahel during which the sovereignty of states has been challenged by inter-state rivalries and military juntas, as well as, in increasing numbers, by non-state actors with self-government, pro-independence or religious claims.

The first 15 years following the independence of the Sahel-Saharan states (1960-75) were characterised by relative stability which, in hindsight, contrasts with the current period. Although there were several coups d'état in the region that ushered in authoritarian regimes in Chad, Mali, Niger and Libya, the relationships between the newly independent states were relatively peaceful and there were few cases of open conflict. Nevertheless, northern Mali experienced its first Touareg rebellion (1962-64), which was brutally crushed by Modibo Keïta's government, and the National Liberation Front of Chad (FROLINAT) was established in Sudan in 1966.

The period from 1975-90 was marked by two major regional conflicts. In the far west region of the continent, the Western Sahara crisis brought Morocco and Mauritania into conflict with the Popular Front for the Liberation of Saguia el-Hamra and Río de Oro (Polisario), an ally of Algeria, as of 1976. The construction by Morocco of several defensive walls between 1980 and 1987 (Map 3) and the ceasefire brokered in 1991 by the United Nations Mission for the Referendum in Western Sahara (MINURSO) confirmed Morocco's de facto control over most of the Western Sahara. In the east, Libya and Chad clashed over the desert area of the Aouzou Strip following its invasion by Libyan forces

Map 3

The advancement of the wall in Western Sahara, 1980-87

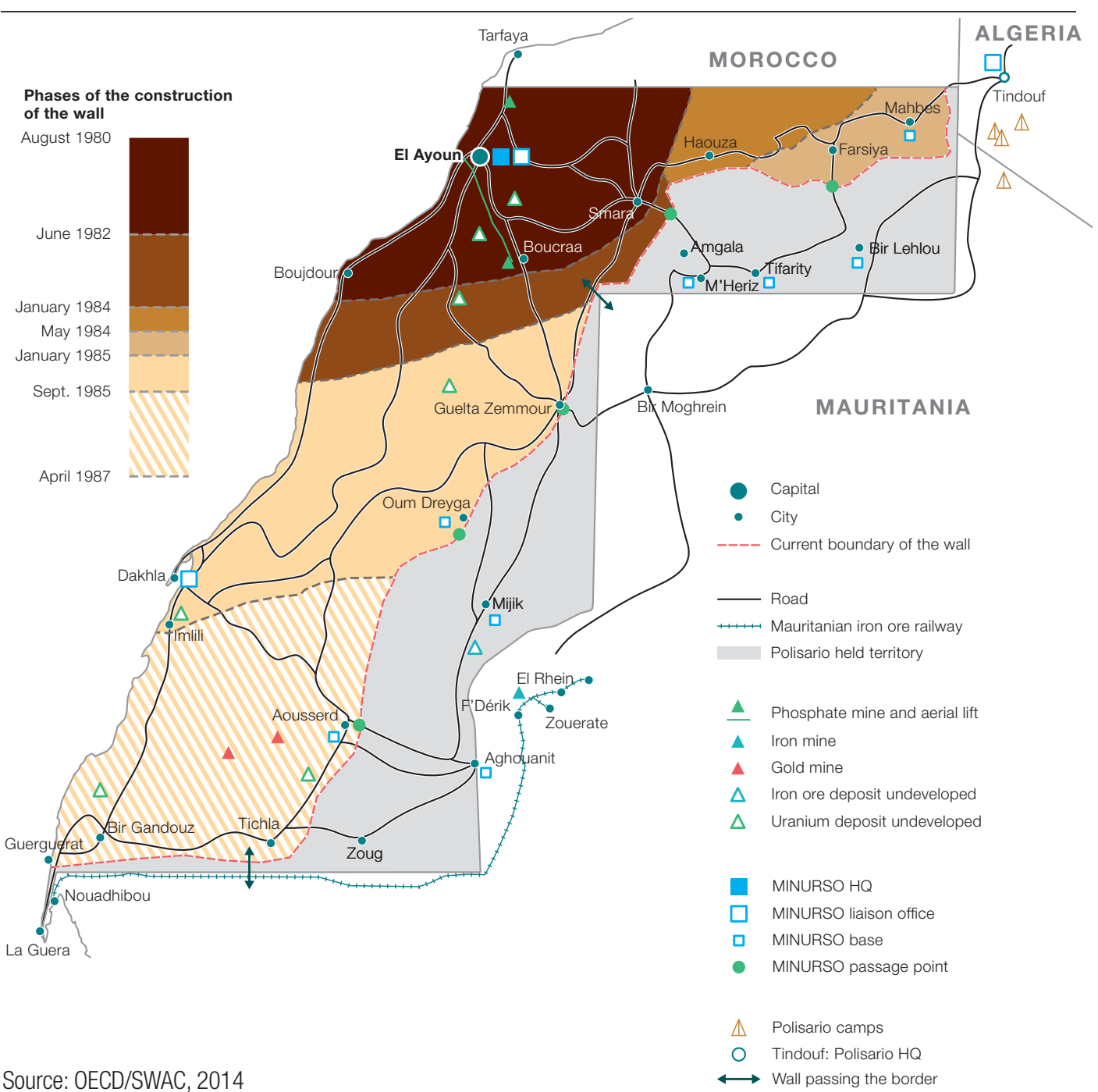


in 1973 (Map 4). After a ceasefire signed in 1987, the International Court of Justice (ICJ) settled the dispute in 1994 when it affirmed Chad's sovereignty. The ICJ was also called on to settle several cross-border disputes in the 1980s, between Burkina Faso and Mali for control of the Agacher strip (1985-86), and between Nigeria and Cameroon in the Lake Chad region and the Bakassi peninsula (1987-2002).

The 1990s heralded the start of a fresh period of instability characterised by an increase in conflicts opposing states, rebels and religious extremists. Between 1990 and 2016, for example, no fewer than 20 armed groups were in open conflict with the government of Mali (Annex), starting with the People's Movement for the Liberation of Azawad (MPLA), whose armed campaign launched in the initial years of democratic transition led to the signing of a National Pact designed to foster Touareg integration into Malian society in 1996. At the same time, a rebellion put into conflict the Nigerien government and several Touareg groups including the Aïr and Azawad Liberation Front (FLAA) and the Armed Co-ordination Resistance (CRA). After numerous atrocities committed by both government and rebel forces, hostilities came to an end with the signing of the Ouagadougou agreement in 1995.

The region was rocked by a second wave of rebellions in the mid-2000s. In Mali, several Touareg leaders of previous rebellions renewed their pro-independence claims by attacking Kidal and Menaka in 2006. The Algiers Agreement signed that year brought a provisional end to the violence, before a new uprising led by the May 23, 2006 Democratic Alliance for Change (ADC) in Mali, and the Nigerien Movement for Justice (MNJ) in Niger brought renewed instability to the region from 2007 to 2009.

\section{Map 4}

Chadian wars, 1973-2002

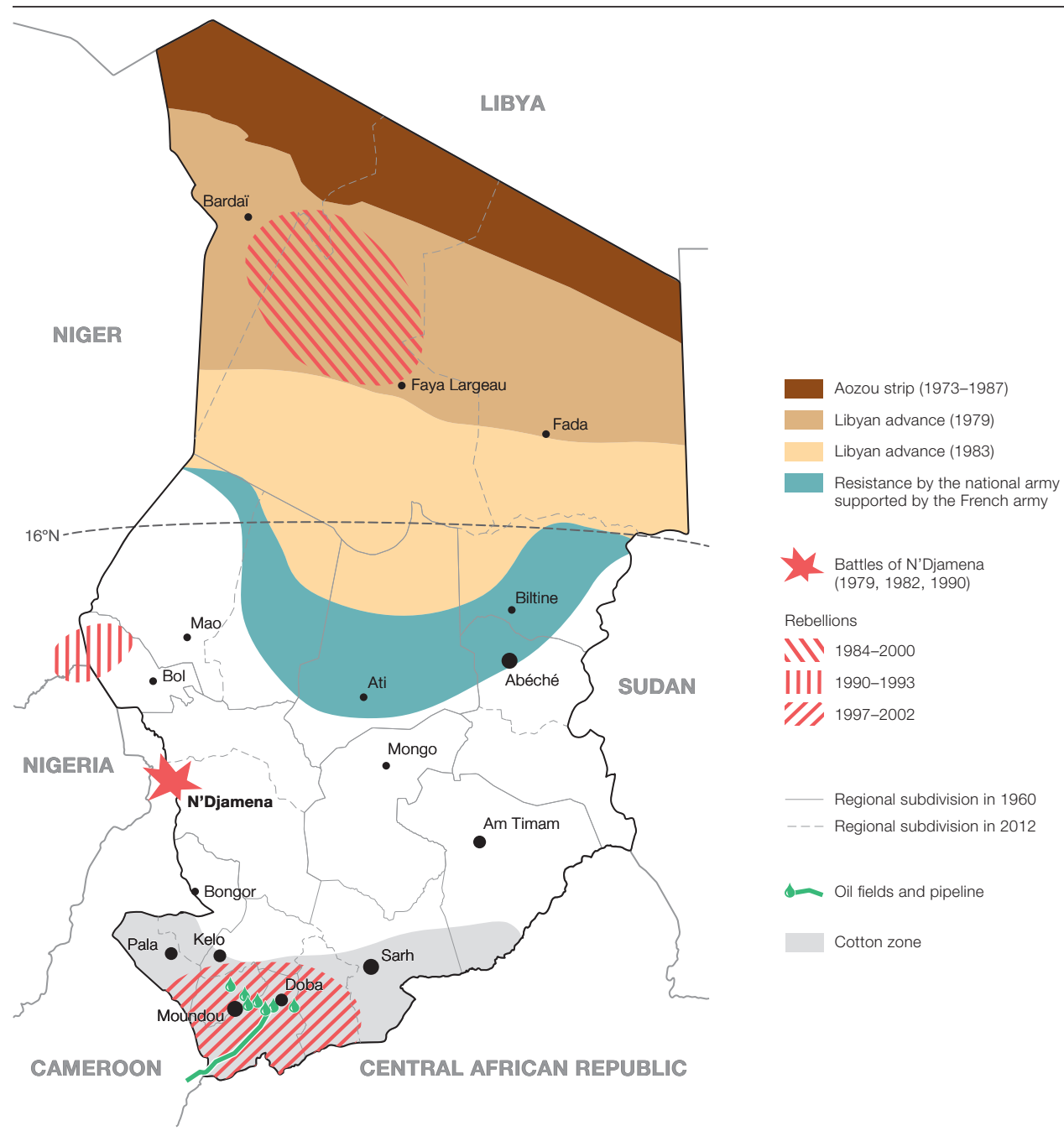

Source: OECD/SWAC, 2014 
These conflicts, frequently interrupted by a series of fragile agreements, affected the internal political balance of Sahel-Saharan states differently. In Niger, the integration of former rebels into the national army and decentralised local authorities helped ease Saharan tensions (Grégoire, 2013). In Mali, by contrast, President Amadou Toumani Touré's (2002-12) policy of trying to govern the north through allied Touareg tribes led to a withdrawal of state institutions, the proliferation of trans-Saharan trafficking and the arrival of extremist groups as of the middle of the 2000s. At the same time, the Libyan Civil War following the overthrow of Colonel Gaddafi in 2011 created a new source of instability in the northern Sahara, leading to many Touareg mercenaries in the Libyan army returning to Mali to take part in the new uprising, and the increased trafficking of small arms from Libyan stockpiles (Marsh, 2017).

In January 2012, the development of religious extremism took on an unprecedented dimension following the circumstantial alliance of extremist group Ansar Dine and Touareg rebels from the National Movement for the Liberation of Azawad (MNLA). Within the space of a few weeks, northern Mali and its key cities had been seized and the government of President Touré replaced by a military junta. The deteriorating security situation led the United Nations Security Council to authorise the deployment of an international force in Mali in December 2012. In January 2013, a new offensive by the religious extremists towards Mopti convinced the acting President of Mali, Dioncounda Traoré, to request the intervention of the French army, which launched Operation Serval. At the end of an operation on a scale not witnessed since the Algerian war, the French army, backed by Malian and Chadian troops, rapidly retook northern Mali and destroyed bases belonging to AQIM, Movement for Oneness and Jihad in West Africa (MUJAO) and Ansar Dine in Timbuktu, Gao, Kidal and in the Adrar des Ifoghas. By restoring Mali's territorial integrity, the French army paved the way for the deployment of the United Nations Multidimensional Integrated Stabilization Mission in Mali (MINUSMA) and the European Union Training Mission in Mali (EUTM Mali).

As of August 2014, the French military forces reconvened under Operation Barkhane to combat terrorist groups (Griffin, 2016) while a political solution to the conflict in Mali failed to materialise. Almost five years after northern Mali was retaken, the insecurity fostered by rivalries between former rebels, religious extremists and factions of the international peacekeeping force remains a concern. Despite the initial success of the Serval military operation, the Malian, African and international forces present in Mali are regularly the target of attacks by Al-Mourabitoun, Ansar Dine, AQIM and the Macina Liberation Front (FLM), united under the name Jama'a Nusrat ul-Islam wa al-Muslimin' (JNIM) since March 2017. Several terrorist attacks have been perpetrated in the south of the country while the authority of the government of Mali remains notional in many jurisdictions in the north which are still home to former Touareg rebels. The mapping of the attacks carried out by the main extremist groups in the region since the start of the Mali war in 2012 illustrates the trans-national activity of AQIM and its affiliates (Al-Mourabitoun, and Those Who Sign in Blood), and Boko Haram (Map 5).

Far from being limited to the confines of the Sahara, the growing instability which marked the early part of the decade beginning 2010 also spread to the countries bordering Lake Chad. The region is faced with a particularly bloody jihadist insurgency which began with the claims of the Boko Haram sect, originally concentrated in the town of Maiduguri, in the Nigerian state of Borno, and which seeks the creation (or restoration) of an Islamic State in Nigeria. After the death of its leader Mohammed Yusuf in 2009, the actions of Boko Haram made themselves felt in spectacular manner, in terms of both its territorial expansion and the number of civilian and military victims of its activities. Military efforts undertaken by the countries bordering Lake Chad and their international partners as of 2013 have helped significantly reduce the number of attacks and victims since 2015 (ICR, 2016) (Figure 2). 
$\underline{\operatorname{Map} 5}$

Victims of the main terrorist groups, 2012-16

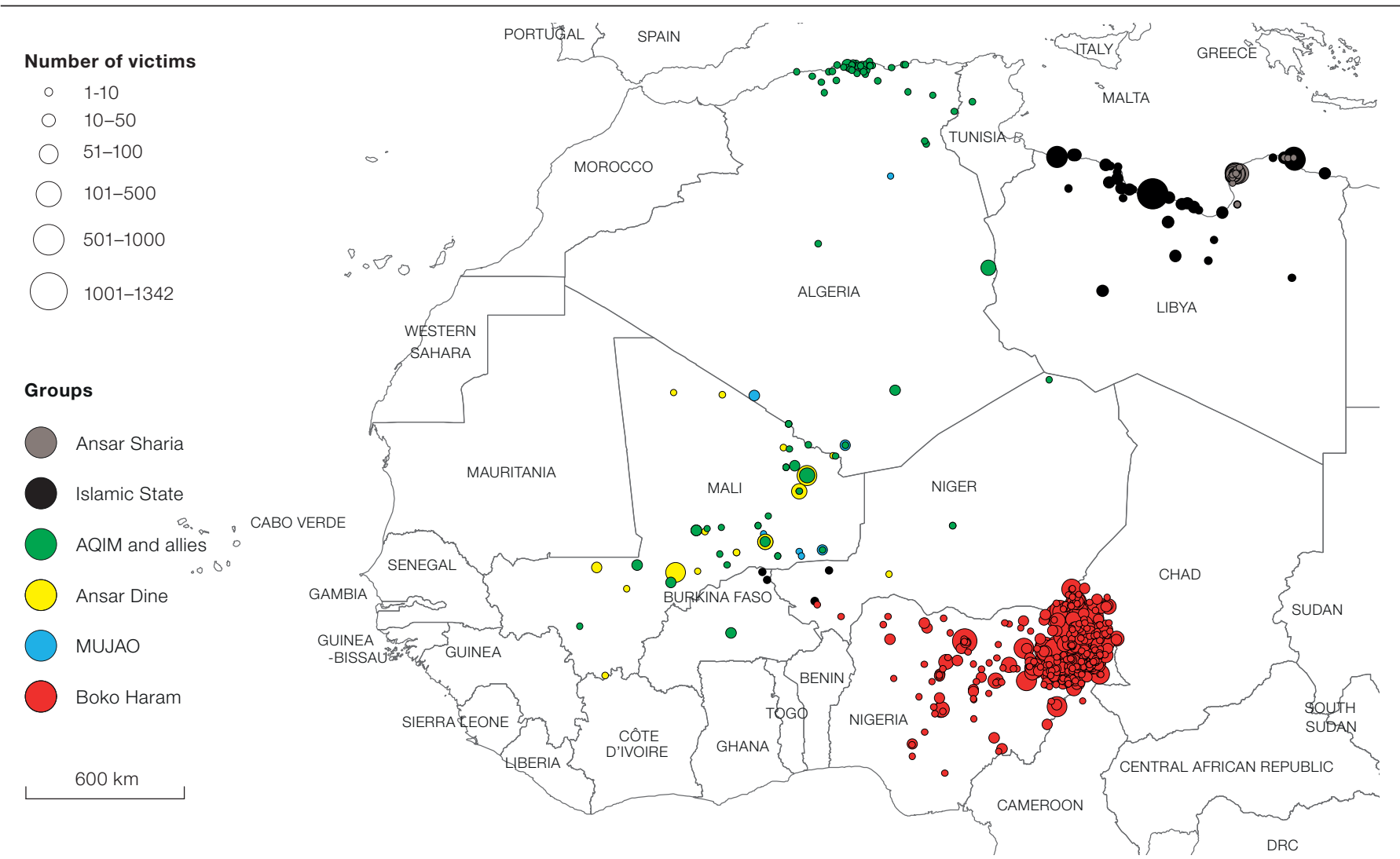

Note: The groups affiliated to Al-Qaeda in the Islamic Maghreb (AQIM) are Al-Mourabitoun and Those Who Sign in Blood. Only violent events attributed to an identified perpetrator are taken into consideration.

Source : ACLED, data 2012-16 (www.acleddata.com/data/africa)

Figure 2

Victims of violence by country, 1997-2016

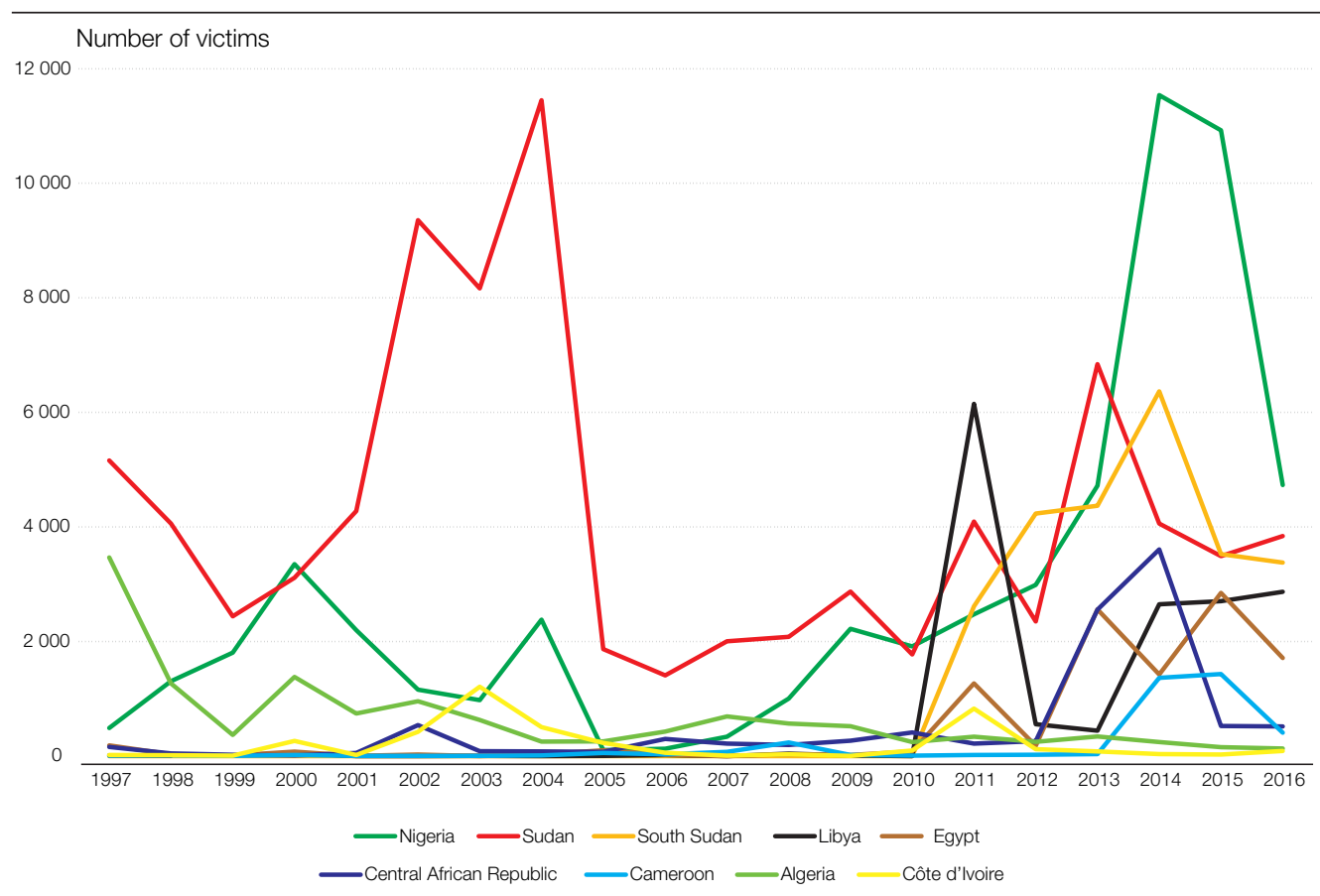

Note: Only the nine countries with the highest numbers of victims are featured. Violent events include "combat", "violence against civilians", "riots and protests, and "remote violence".

Source: ACLED, data 1997-2016 (www.acleddata.com/data/africa). 
The recurring conflicts between states and non-state organisations have added to the domestic disorder within Sahel-Saharan states, which has by no means disappeared since the end of the Cold War. There have been eight successful coups d'état since the end of the transitions to democracy in the 1990s, in Mauritania $(2005,2008)$, Niger, $(1996,1999$, 2010), Chad (1990), and Mali (1991, 2012). Although they resulted in few casualties, they nevertheless destabilised the democratic institutions and encouraged the presidential elites to invest in elite corps rather than the armies responsible for national security. In Mali and Burkina Faso, these highly specialised units responsible for guarding the president (parachute commandos and the Regiment of Presidential Security) have been reintegrated into the army or disbanded. On top of the coups d'état came the popular protest movements which began at the end of 2010 and led to renewed political violence and religious extremism in Tunisia and Libya, as well as widespread demonstrations in Mauritania.

\section{THE SPECIFICITIES OF WARS AND CONFLICTS IN THE SAHARA-SAHEL}

$\mathbf{F}$ ar from being completely unpredictable and chaotic, the outbreaks of violence in the Sahara-Sahel are governed by a number of organisational principles, which help clarify the geographic scale of the conflicts, the relationships between warring parties, their objectives and their military strategies.

\section{Local, global and cross-border conflicts}

From a geographic point of view, the first characteristic of Sahelo-Saharan conflicts is that they leverage global ideas and resources to pursue local and national claims. Boko Haram, for example, exploits the historical narrative of the Kanem-Bornu empire, which reigned over the Lake Chad Basin and its Saharan extension for around 1000 years, to contend that its political claims follow a historical continuity interrupted by colonial conquest (Barkindo, 2016). By situating its roots in local history, the group can justify its policy of political renewal and its rejection of institutional structures tied to colonisation, including the Federal Republic of Nigeria. At the same time Boko Haram exploits the pan-Islamist vision of a unified Muslim world, whose boundaries transcend national borders to embrace all believers. With this in mind, the group pledged allegiance to the Islamic State in 2015, without, however, deriving any substantial operational benefits from this move (Gartenstein-Ross and Zenn, 2016). Mapping reveals a certain consistency between the extension of the medieval Kanem-Bornu empire and the attacks carried out by Boko Haram since 2009, when the group started resorting to political violence (Map 6). According to ACLED data, the 2074 recorded attacks, resulting in over 28000 victims, have been particularly focused on the State of Bornu, and the towns of Maiduguri (307), Damboa (57), Damaturu (49), as well as the city of Kano (49) and the twin towns of Gambaru and Fotokol (43) on the border with Cameroon.

Moreover, the wars and conflicts in the region are propped up by global resources which are then invested into struggles driven by local and national aspirations. The initiators of conflicts in the Sahara-Sahel have developed predatory strategies which exploit local resources when they exist (fishing around Lake Chad), often illegal trans-Saharan flows of people and merchandise, and more global resources provided by humanitarian organisations. In other regions of sub-Saharan Africa, the rebels use the refugee camps and the food provided by humanitarian organisations to prolong their struggle, whereas it seems that in the Sahara-Sahel, the main currency enabling religious extremist groups to purchase weapons and vehicles and curry favour with local Arab and Touareg leaders is European hostages. In Mali in particular, the unofficial ransoms paid by European governments in exchange for their hostages represent amounts estimated at several tens of millions of dollars (Daniel, 2012). 


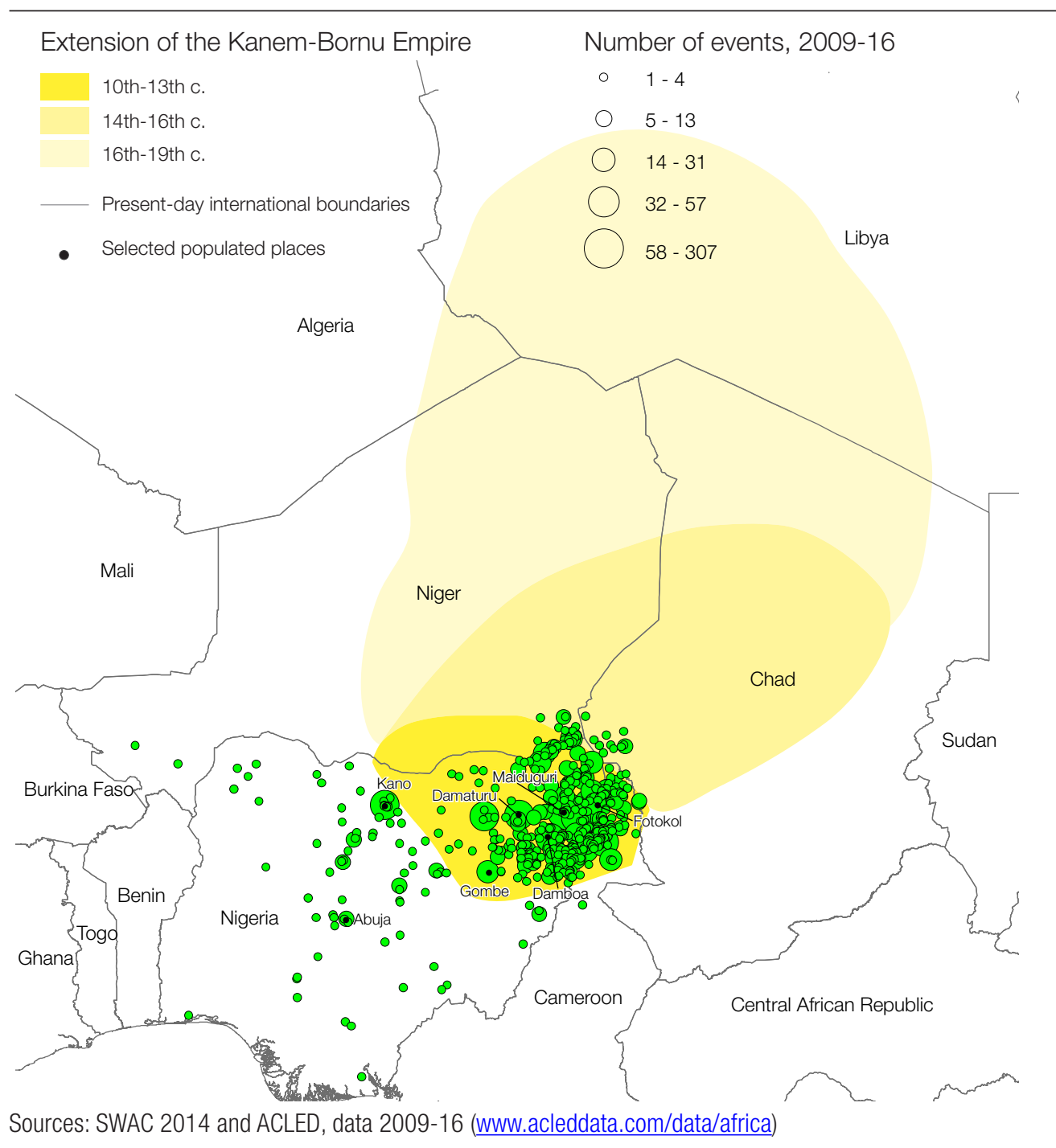

The second geographic characteristic of Sahelo-Saharan conflicts is their ability to spill over the formal framework of state borders, thereby blurring the traditional lines between domestic and foreign affairs (Walther and Miles, 2018). From the Atlantic to the Ennedi, all the Sahel-Saharan states have strengthened the surveillance of their border areas in order to combat the proliferation of rebel and terrorist groups. This can be seen in border regions far from capital cities, such as the Hodh area in Mauritania, the Wagadou forest in Mali, the Gourma area of Burkina Faso, Djado in Niger, and the Lake Chad basin. These initiatives have received support from Operation Barkhane, one of the aims of which is to destabilise cross-border terrorist networks in some of the most inaccessible regions of the Sahara. In some cases, government forces have used their right of hot pursuit to intervene in neighbouring countries, as in Mauritania launched military operations with the support of the French army to destroy AQIM bases on Malian soil (Harmon, 2014). In the Lake Chad region, the regional threat posed by Boko Haram also prompted Cameroon, Chad, Niger and Nigeria to revive the Multinational Joint Task Force (MNJTF), originally created to fight banditry but now mainly focused on counter-terrorism.

For the rebels and religious extremists, the porous borders of Sahelo-Saharan Africa provide relatively easy freedom of movement between the different countries in the region for the purposes of carrying out attacks, replenishing their weapons or recruiting new fighters. As in Liberia and Sierra Leone, and the vast forests of Central Africa which are home to the Lord's Resistance Army (LRA), the border areas of the Sahel and the Sahara are 
used as a rear base for groups seeking to protect themselves from government offensives. In that respect, the recent history of the region demonstrates that the regionalisation of conflicts follows the principle of communicating vessels; when placed under increasing pressure, armed groups relocate to countries where there is less military capacity or political inclination to fight them.

Accordingly, as of the middle of the 2000s, northern Mali became the refuge for the GSPC, whose roots can be traced to the conflict between the Algerian government and various Islamist groups between 1991 and 2002. Under constant pressure from the Algerian army, the GSPC moved into Algeria's Saharan provinces and neighbouring areas. In 2003, the group pulled off the dramatic kidnapping of a group of European tourists in the Algerian desert and pushed into northern Mali before crossing the Nigerien desert to Chad, where its leader Amari Saifi (also known as Abderrazak le Para) was captured by rebels from the Movement for Democracy and Justice in Chad (MDJT). Between 2004 and 2011, the mobility of AQIM and other extremist groups moving between Mauritania, Algeria, Mali, Niger and Chad was at its peak (Walther and Miles, 2018), and enabled their leaders to forge links with local tribes, develop a hostage-taking industry and recruit an increasing number of local fighters of Touareg, Arab, Fulani and Songhay origin.

In the last decade, Boko Haram has grown on a similar scale, from a militant group mainly driven by national objectives to an international network present in a growing number of countries (Dowd, 2018). From 2009 to 2012, with the insurgency growing in intensity and expanding geographically from Maiduguri to affect 19 of the country's states, most of the group's attacks took place on Nigerian soil (99\%). There was a change of strategy in 2014, when the number of attacks in Cameroon accounted for $16 \%$ of the total. In 2015, at the height of the insurgency, over 28\% of the group's 597 attacks took place outside of Nigeria. Since then, having seen its operational capacities reduced and after being forced to relinquish territorial control, Boko Haram seems to have adopted an opportunistic relocation strategy in neighbouring Cameroon, Chad and Niger which makes the combined efforts of the MNJTF all the more crucial.

\section{Widely varying alliances and rivalries}

Another unsettling aspect of the conflicts in the Sahara-Sahel is that they set in opposition a small number of markedly different actors. In addition to government forces and their allied militias, these conflicts involve ethnic or religious self-defence groups, rebels groups fighting for independence or greater autonomy, terrorist organisations, warlords and criminals. The relationships between these actors are characterised by widely varying alliances and rivalries (Bencherif and Campana, 2016). At the start of the conflict in Mali, for example, the Islamist group Ansar Dine and the pro-independence Touareg movement MNLA formed an uneasy alliance to overthrow the main towns in Mali. Once this had been achieved, these two protagonists with fundamentally diverging interests turned on each other in a violent confrontation.

Rebellion movements are often fragmented into competing factions reflecting tribal, ethnic, social and economic divisions within Sahelo-Saharan societies. For example the Touareg tribes of noble origin, such as the Ifoghas in north eastern Mali, have conflictual relationships with other tribes which were traditionally their vassals (the Imghad) as well as with noble tribes from other regions. These rivalries are also behind cleavages in opposition movements, which prevent any supranational unification. Accordingly, despite a close cultural heritage and similar demands for autonomy, Touareg rebels from Mali and Niger have never merged. Since the severe droughts in the 1970s, high levels of economic inequality have also developed between a minority who have grown rich on migration, mercenary activities and trans-Saharan trafficking, and the rest of the population who depend on pastoral herding and tourism, two sectors affected by climatic and political instability. 
While it is true that many armed groups combine pan-Islamist claims and local demands, it is by no means certain that the aforementioned internal divisions may one day be overcome by an ideological project such as the restoration of a theological order. The group Ansar Dine, for example, whose name means Defenders of the Faith, builds on a religious agenda for all Muslims, despite mainly comprising members of noble Touareg tribes. In this regard, the current rebellions and insurgencies in the Sahara-Sahel are very different from the Maoist-based opposition movements which appeared during the Cold War and whose strength lay in a hierarchical military structure seamlessly integrated into a political apparatus (Knoke, 2013).

The mapping of the relationships between the 15 leading warring parties in the Malian conflict in 2015 confirms that conflictual relationships far outweigh coalitions in the region. From this point of view, the structural position of the MNLA is particularly precarious, given that it has conflictual relationships with the government of Mali, religious extremists (since 2013) and the GATIA group (Imghad and Allied Touareg Self Defence Movement) led by El Hadj Ag Gamou (Figure 3). The constantly changing Islamist groups also have numerous enemies. The mapping of the co-operative relationships between the actors in the Malian conflict on the other hand reveals an extremely fragmented security landscape and the isolation of the government of Mali, which can only count on the support of one militia and the United Nations. Despite their rivalries, the Islamist organisations affiliated to Al-Qaeda form a cluster of wider alliances, whereas the rebels are split into two camps based on their relationships with the government. Government, rebel and Islamist forces therefore form three components of a security environment in which no single party is really in a position to join forces with one of the other camps and provide a lasting solution to the conflict.

\section{Figure 3}

Conflictual and co-operative relationships between actors in the Malian conflict in 2015

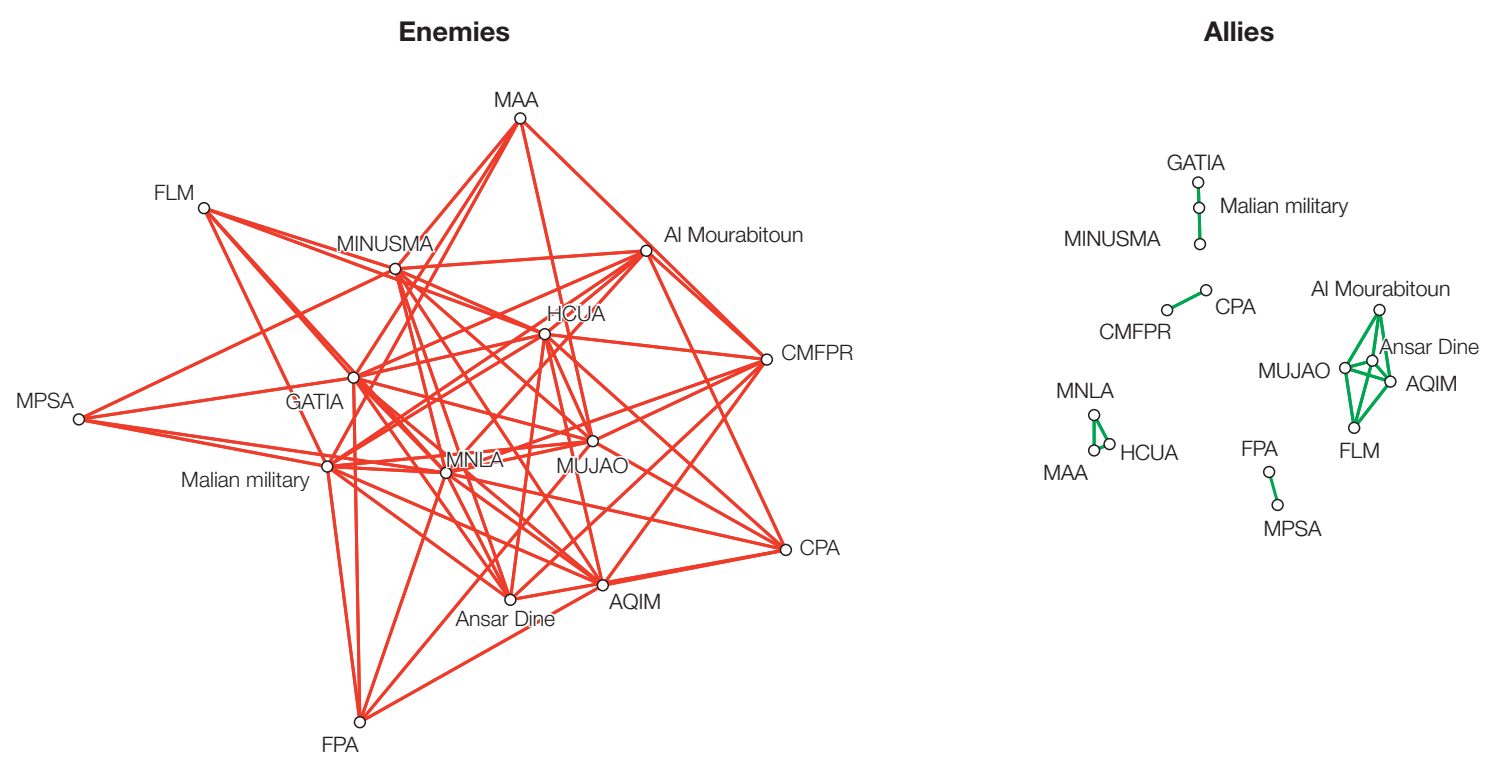

Source: Walther and Tisseron 2015, reproduced with the permission of The Broker.

The absence of a lasting coalition in the region is due to the fact that alliances between groups ebb and flow with the balance of power between conflicting parties. For example, during the French offensive in 2013, many Ansar Dine fighters joined the MNLA and the Islamic Movement for Azawad (MIA) created by Alghabass Ag Intalla, an Ifoghas Touareg 
who fought on the side of the MNLA and then Ansar Dine. Several months later, the MIA joined the High Council for the Unity of Azawad (HCUA) led by Alghabass's brother, Mohamed Ag Intalla, in order to take part in the peace talks. Whereas peace talks often lead to the creation of temporary coalitions, the signing of peace agreements often leads to the fragmentation of groups, which fall apart after the disappearance of a common enemy. In addition to political factors, trafficking in arms, cigarettes and drugs are also a source of rivalry between groups, particularly along trans-Saharan routes.

The allegiance of soldiers and military leaders is also highly volatile, and they regularly switch sides depending on whether it is the government forces, rebels or religious extremists who have the upper hand. Iyad Ag Ghaly, the current Ansar Dine leader, from a noble Ifoghas Touareg family from the Kidal region, was successively a mercenary in Colonel Gaddafi's Islamic Legion, a rebel, a negotiator for the government of Mali, and a diplomat posted to Saudi Arabia before seeking to take over the MNLA. Brigadier general El Hadj Ag Gamou, from a family of vassal Touaregs from northern Mali, followed a path that was almost as convoluted, having fought in the Islamic Legion in Libya and returned to Mali as a rebel, before joining the Malian army and forming the pro-government selfdefence movement GATIA.

\section{Exclusive identity politics}

Many present day conflicts in the Sahara-Sahel are not rooted in geopolitical and ideological considerations, but in assertions of identity. In her work entitled New Wars and Conflicts (2012), Mary Kaldor used the term “identity politics" to qualify armed struggles based on ethnic, racial or religious identity. These movements were helped by the gradual disillusionment in the postcolonial secular regimes which followed the Cold War. Unlike the Maoist-based movements based on transforming the peasantry into a new action force which would transcend any former divisions, the identity-based movements develop an idealised vision of the past, such as the Caliphate promised by Islamic State and Boko Haram.

This political vision, built on fear, hatred and destruction, taps into extreme ideas for the creation of ethnically or religiously homogeneous areas. The destruction by Ansar Dine extremists in 2012 of nine mausoleums and the door of the Sidi Yahia mosque in Timbuktu was consistent with this way of thinking. The aim of this initiative, carried out a few days after UNESCO had added the city to the List of World Heritage in Danger, and which left both the local population and the international community equally stunned, was to desecrate any religious symbols considered to be unorthodox by the extremists. It echoed the destruction of the Buddhas of Bamiyan by the Taliban in 2001, and heralded the methodical destruction by Islamic State of cultural heritage in Iraq, Libya and Syria as of 2014 .

Beyond attacks on cultural heritage, one of the most dramatic consequences of these identity politics is that civilians are considered to be the main targets in conflicts, and no longer accidental victims. This is not specific to the Sahel-Sahara; most of the civilian casualties in African conflicts have been deliberately targeted by combatants. This deliberate desire to kill or displace civilians in order to create ethnically or religiously homogeneous areas differentiates contemporary insurgencies in sub-Saharan Africa from older guerrilla wars, where the aim was to win over the local population, on whom the insurgents depended for their survival. This illustrates the fact that the objective of the present day wars and conflicts in the Sahel and the Sahara is not to defend a territory but to control its population. As General Linder, the former commander of Special Operations Command-Africa, said, "In Africa, it's never about seizing terrain" (quoted in Griswold, 2014) to express the impossibility of exercising military control over the whole territory. 


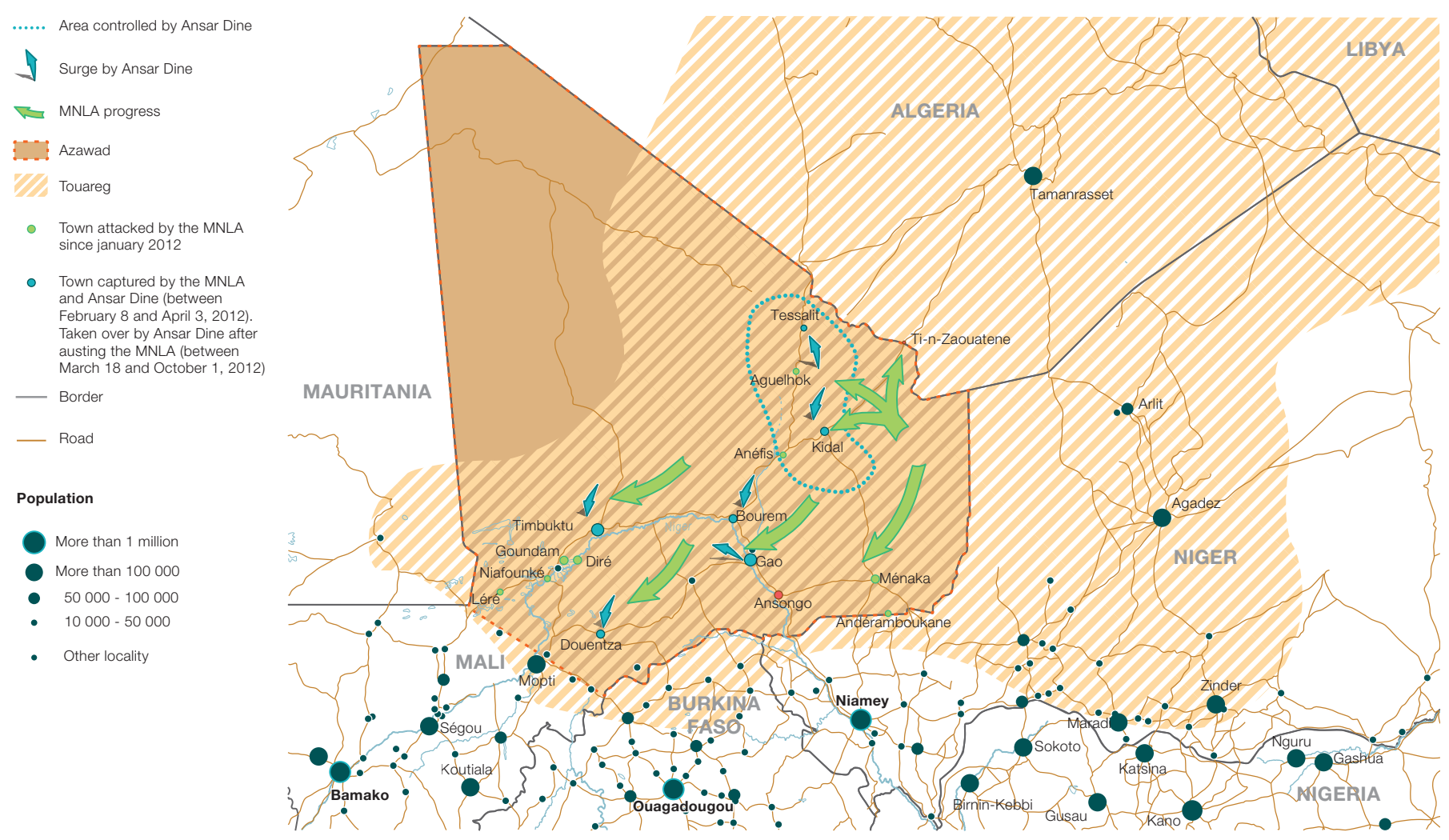

Source: OECD/SWAC, 2014

From this point of view, the conflict in Mali demonstrated that the pro-independence rebels and religious extremists were far less interested in exerting their authority over the whole of northern Mali, which the rebels call Azawad, than in seizing a certain number of strategic towns and trans-Saharan routes necessary for controlling the population (Retaillé and Walther, 2013). These towns were first and foremost Kidal and Tessalit, in far north eastern Mali, then Gao, Bourem and Timbuktu located in the Niger belt (Map 7).

For most of the past 20 years, the leading cause of death in the conflicts in West and North Africa has been violence resulting from battles between government forces, rebels, militias and organised ethnic communities, followed very closely by violence against civilians (Figure 4). A similar trend has been observed in the G5 Sahel (Mauritania, Mali, Burkina Faso, Niger and Chad), mainly situated in the Sahelo-Saharan zone. There are comparatively fewer victims of remote violence resulting from the use of bombs, improvised explosive devices (IEDs), mortars and missiles, and riots and demonstrations.

The civilian casualties recorded here were victims of violence by governments, rebels, militias and rioters against unarmed populations (Raleigh and Dowd, 2015). However, they do not include the victims of disease, malnutrition and enforced movement brought on by conflicts. These side effects, which are often delayed, considerably increase the price paid by civilians in African conflicts. Generally speaking in West Africa, the main sources of nutritional insecurity are also conflict regions (PREGEC, 2017), whether it be Liptako-Gourma, northern Mali or the Lake Chad region, where the Boko Haram insurgency forced over 220000 people to seek shelter in neighbouring countries and resulted in over 2.3 million internally displaced persons (UNHCR, 2017, see also World Bank and UNHCR, 2016). 
Figure 4

Victims by type of violence, West and North Africa, 1997-2016

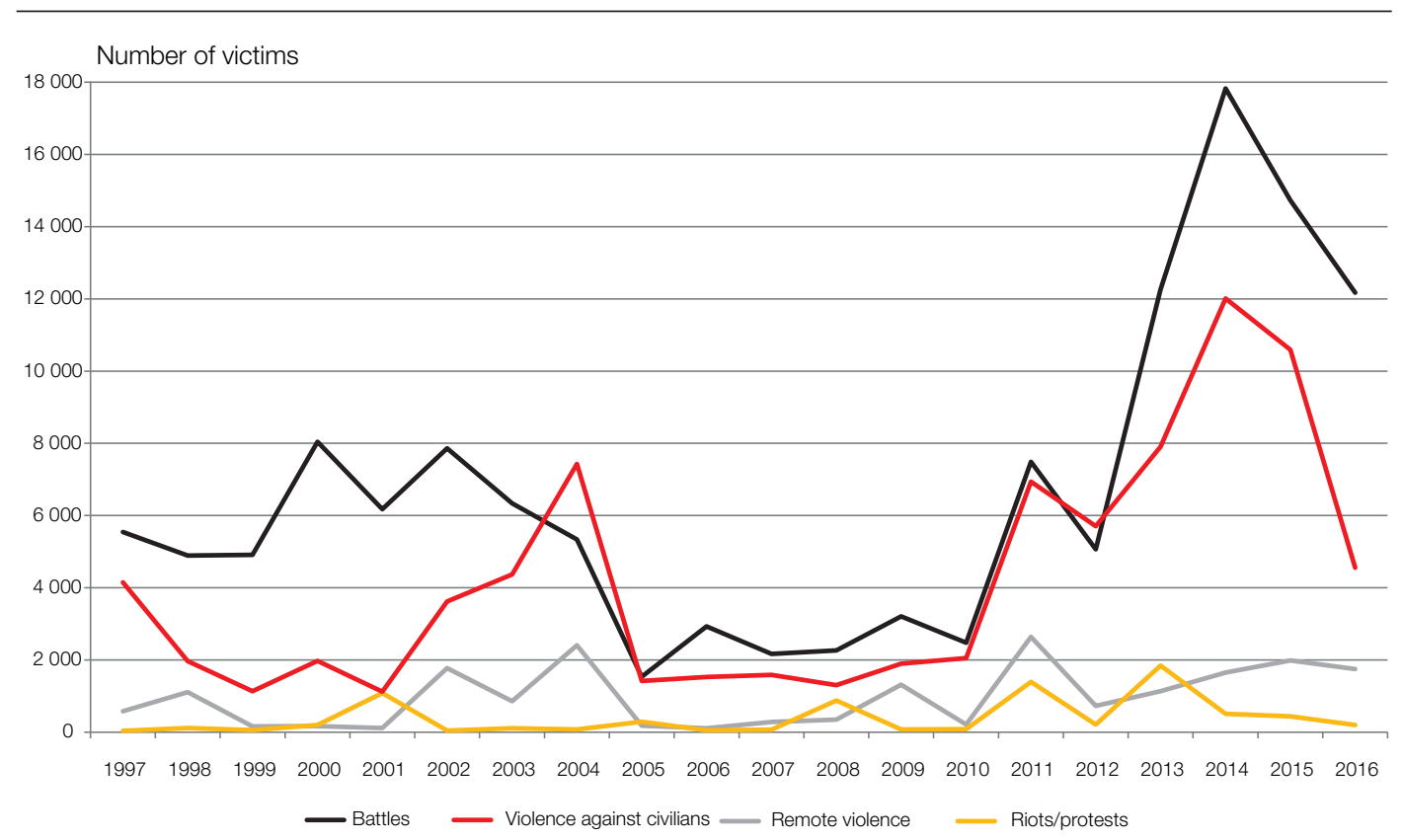

Source: ACLED, data 1997-2016 (www.acleddata.com/data/africa)

\section{Mobile armed groups}

From a military perspective, the protagonists of the conflicts in the Sahel and the Sahara tend to avoid direct confrontation with regular troops. Modern Sahelo-Saharan conflicts are usually characterised by a succession of inconclusive skirmishes which involve a limited number of fighters and which can occur several hundred kilometres apart. This reinforces the impression that the Sahelo-Saharan conflicts have no discernible beginning or end and affect the entire region, without any apparent logic. The unlawful combatants, who invest as little as possible in heavy equipment, make up for their low numbers with their great mobility. T.E. Lawrence (1920) had already observed this principle in Arabia when he stated that in the desert "space [was] greater than the power of armies" and he likened the principles of war in the desert to naval warfare. At sea, as in the desert, the insurgents are mobile, relatively autonomous from fixed bases and indifferent to the restraints of their environment.

In this respect, the Malian conflict was evidence that the military resources of the rebels and religious extremists could not match those of a modern army. Because they forgot this fundamental principle of asymmetrical conflicts and assembled a large number of their pickup trucks with a view to attacking Mopti, the extremists of Ansar Dine, MUJAO and AQIM were swiftly defeated in the first weeks of January 2013 (Chivvis, 2015). During Operation Serval which led to the recapture of northern Mali, on the other hand, MNLA rebels offered little resistance and preferred to flee rather than fight the French forces. Timbuktu, Gao and Kidal were retaken with very little fighting, despite being the historical cradle of Touareg rebellions. The main area where the Malian conflict took the form of a direct confrontation between French and Chadian forces on one side and AQIM insurgents on the other was in the valley of Ametetai, south-east of Tessalit. Since then, the most common form of military confrontation has been suicide bombings or IEDs aimed at multinational convoys and Malian army bases. 


\section{INSTITUTIONAL SOLUTIONS}

$\mathrm{n}$ the previous sections, this paper examined the particularities of the security situation in the Sahel and the Sahara, which are currently faced with exceptional political instability involving a combination of rebellions, jihadist insurgencies, coups d'état, protest movements and illegal trafficking. It showed that the region is not just a victim of an escalation of the wars and conflicts which marked the $20^{\text {th }}$ century, but that it has also become the setting for three types of organised violence: armed struggles for a political purpose, criminal activities for sake of personal gain, and human rights violations. The current backdrop to these patterns of violence is a global security environment, which blurs the traditional lines between what is local and global, domestic and international, military and civilian, politics and identity.

The military and civil solutions put in place by the states in the region and their international partners have to take account of the fact that the armed struggles in the region are being carried out in a globalised environment which is redefining the scale of conflicts and the relationships between warring parties.

The deterioration of the security situation over the last fifteen years demonstrates that military solutions must be found and applied at a regional basis. From this point of view, the Malian conflict was a catalyst for numerous regional initiatives designed to promote security, governance and development in the region. These actions received the support of the UN Security Council in June 2017 and culminated in the creation by the G5 Sahel States of a joint military force. The newly created "Alliance for the Sahel" is expected to result in the co-ordination of the previously disparate initiatives by the region's principal donors.

At the same time, it also appears that long-term conflict resolution entails restoring the legitimacy of governments, which has been undermined "from below" by the proliferation of armed groups. The contradictory agendas and unpredictable alliances formed by these groups finish by blurring the customary distinction between government, the national army and society, which was previously one of the cornerstones of the modern states in the region. In recent decades, military interventions and international legal proceedings have also often superseded states "from above" when the latter have proved incapable of defending their territory, maintaining domestic order and protecting their cultural heritage. The most dramatic example of this is in Mali, where the national armed forces are operationally incapable of defending their national territory and maintaining domestic order without the support of some 15000 soldiers from the United Nations mission and France, and unable to respond to the destruction of their cultural heritage without appealing to the International Court of Justice. Lastly, the legitimacy of Sahel-Saharan states is subject to increased competition from non-governmental organisations whose actions, despite being driven by humanitarian reasons, end up elbowing out public services, especially during conflicts.

Crisis resolution also requires finding inclusive governance solutions within each state. The fact that civilians pay such a high price in the current conflicts should encourage the authorities to use the minimum necessary force in their anti-insurgency operations. A strategy aimed at protecting the civilian population from violence and gaining their support is the best way of countering the strategies of extremist groups based on fear and exclusion. This strategy can entail the creation of secure regions where alternative, more inclusive forms of policy are put in place by establishing a dialogue between the states and local actors known for their integrity more than their opportunism, and initiatives to rehabilitate rebels and religious extremists. More generally, conflict resolution has to involve the recognition of the virtues of diversity and cosmopolitanism, two vital ingredients in fighting identity politics. 


\section{NOTES}

1 Wars are armed struggles between States and/or non-state actors. They begin with a declaration of war and end with an agreement officially signalling the end of hostilities (peace treaty, surrender). Conflicts are characterised by a state of protracted struggle between persons, organisations, or countries, with no formal declaration marking their beginning and end.

2 The region under consideration here covers the 15 countries comprising the Economic Community of West African States (ECOWAS) along with Mauritania, Cameroon, Chad, Sudan and South Sudan. In North Africa, the data cover Morocco, Western Sahara, Algeria, Tunisia, Libya and Egypt. As for the Sahara-Sahel, it is not defined as a group of countries but as an area of movement which opens on to the Mediterranean cities in the North and on to the West African markets and production areas in the South.

3 Boko Haram, whose abridged etymology from Hausa is contested, called itself Jamā'at Ahl as-Sunnah lid-Da'wah wa'l-Jihād (the Sunn People Committed to the Prophet's Teachings for Propagation and Jihad) until 2010, and al-Wilāyat al-Islāmiyya Gharb Afrīaiyyah (Islamic State, province of West Africa) since it pledged allegiance to Islamic State in 2015. 


\section{REFERENCES}

ACLED (2016), Armed Conflict Location and Event Data. Africa Data 1997-2016, version 7. Available at: www.acleddata.com/data/acled-version-7-1997-2016.

Barkindo, F.A. (2016), "How Boko Haram exploits history and memory", Africa Research Institute, London, https://www.africaresearchinstitute.org/newsite/publications/boko-haram-exploits-history-memory/ (accessed on 12 July 2017).

Bencherif, A. and A. Campana (2016), "Alliances of convenience: Assessing the dynamics of the Malian insurgency", Mediterranean Politics, Vol. 22/1, pp. 115-134.

Chivvis, C.S. (2015), The French War on Al Qa'ida in Africa, Cambridge University Press, Cambridge.

Daniel, S. (2012), AQMI. L'industrie de l'enlèvement, Fayard, Paris.

Dowd, C. (2018), "Nigeria's Boko Haram: Local, national and transnational dynamics", in Walther, O. and W. Miles (eds.), African Border Disorders, Routledge, Abingdon, pp. 115-135.

Gartenstein-Ross, D. and J. Zenn (2016), "Boko Haram's doomed marriage to the Islamic State", War on the Rocks 26 August, https://warontherocks.com/2016/08/boko-harams-doomed-marriage-to-the-islamic-state/ (accessed on 12 July 2017).

Global Terror Watch (2017), Groupes armés, liste par pays. Geneva, www.globalterrorwatch.ch/index.php/groupesarmes-liste-par-pays.

Grégoire, E. (2013), "Islamistes et rebelles touaregs maliens : Alliances, rivalités et ruptures”, EchoGéo, http://echogeo. revues.org/13466 (accessed on 12 July 2017).

Griffin, C. (2016), "Operation Barkhane and Boko Haram: French counterterrorism and military cooperation in the Sahel”, Small Wars \& Insurgencies, Vol. 27/5, pp. 896-913.

Griswold, E. (2014), "Can General Linder's Special Operations Forces stop the next terrorist threat?", The New York Times, 13 June.

Harmon, S.A. (2014), Terror and Insurgency in the Sahara-Sahel Region, Ashgate, Farnham.

ICG (2016), "Boko Haram on the back foot?", International Crisis Group Africa Briefing 120.

Kaldor, M. (2012), New and Old Wars. Organized Violence in a Global Area, Stanford University Press, Palo Alto.

Knoke, D. (2013), "It takes a network: The rise and fall of social network analysis in U.S. Army counterinsurgency doctrine", Connections, Vol. 33/1, pp. 1-8.

Lawrence, T.E. (1920), "The evolution of a revolt", Army Quarterly and Defense Journal, October, http://usacac.army.mil/cac2/cgsc/carl/download/csipubs/lawrence.pdf (accessed on 12 July 2017).

Marsh, N. (2017), "Brothers came back with weapons. The effects of arms proliferation from Libya", PRISM, Vol. 6/4, pp. 79-96.

Melander, E., T. Pettersson and L. Themnér (2016), “Organized violence, 1989-2015”, Journal of Peace Research, Vol. 53/5, pp. 727-742.

OECD/SWAC (2014), An atlas of the Sahara-Sahel: Geography, Economics and Security, OECD Publishing, Paris, http://dx.doi.org/10.1787/9789264222359-en.

PREGEC (2017), "Communiqué on the Food and Nutrition Situation (June-August) and the 2017-18 Agropastoral Outlook", Praia, Regional System for the Prevention and Management of Food Crises (PREGEC)", www.oecd.org/ site/rpca/documents/RPCA Avis PREGEC Juin2017 EN.pdf (accessed on 12 July 2017).

Raleigh, C., A. Linke, H. Hegre and J. Karlsen (2010), "Introducing ACLED-Armed Conflict Location and Event Data", Journal of Peace Research, Vol. 47/5, pp. 651-660.

Raleigh, C. and C. Dowd (2015), "Armed Conflict Location and Event Data Project (ACLED) Codebook", https://www.acleddata.com/wp-content/uploads/2015/01/ACLED_Codebook_2015.pdf (accessed on 12 July 2017).

Retaillé, D. and O. Walther (2013), "Conceptualizing the mobility of space through the Malian conflict", Annales de géographie, Vol. 6, pp. 595-618.

UNHCR (2017), "Nigeria situation”, https://data2.unhcr.org/en/situations/nigeriasituation (accessed on 12 July 2017).

United Nations (2017), Security Council Welcomes Deployment of Joint Force to Combat Terrorism Threat, "Transnational Crime in Sahel, Unanimously Adopting Resolution 2359" ", United Nations, New York, https://www.un.org/press/ en/2017/sc12881.doc.htm (accessed on 12 July 2017).

United States Department of State (2017), Foreign Terrorist Organizations, Washington, DC, https://www.state.gov/j/ct/ rls/other/des/123085.htm.

Walther, O. and A. Tisseron (2015), "Strange bedfellows: a network analysis of Mali's northern conflict", The Broker, 18 December, www.thebrokeronline.eu/Articles/Strange-bedfellows-a-network-analysis-of-Mali-s-northern-conflict (accessed on 12 July 2017).

Walther, O. and W. Miles (eds.) (2018), African Border Disorders. Addressing Transnational Extremist Organizations, Routledge, Abingdon.

Walther, O., C. Leuprecht and D. Skillicorn (2018), "Networks and spatial patterns of extremist organizations in North and West Africa", in Walther, O. and W. Miles (eds.), African Border Disorders. Routledge, Abingdon, pp. 60-86.

Williams, P. (2011), War and Conflict in Africa, Polity Press, Cambridge.

World Bank and UNHCR (2016), "Forced Displacement by the Boko Haram conflict in the Lake Chad region", Geneva and Washington, DC, https://data2.unhcr.org/en/documents/details/52535 (accessed on 12 July 2017). 
ANNEX: ARMED GROUPS IN OPEN CONFLICT WITH SAHELSAHARAN STATES, JANUARY 1990-DECEMBER 2016

\begin{tabular}{|c|c|}
\hline Country & Armed group \\
\hline Algeria & $\begin{array}{l}\text { Al-Qaeda } \\
\text { Al-Qaeda in the Islamic Maghreb (AQIM) } \\
\text { Al Moulathamoun (Those Who Sign in Blood) } \\
\text { Al-Mourabitoun (The Sentinels) } \\
\text { Ansar Dine } \\
\text { Armed Islamic Group (GIA) } \\
\text { Islamic Movement for Azawad (MIA) } \\
\text { Ennour Brigade } \\
\text { Farouq Brigade } \\
\text { Free Salafist Group (GSL) } \\
\text { Humat al-Da'wa al-Salafiya (Protectors of the Salafist Call) } \\
\text { Islamic League for Da'wa and Jihad (LIDD) } \\
\text { Islamic Salvation Army and Islamic Salvation Front (AIS, FIS) } \\
\text { Jama'at al-Muslimiin } \\
\text { Movement for Oneness and Jihad in West Africa (MUJAO) } \\
\text { Okba Ibn Nafaa Brigade } \\
\text { Salafia Jihadia } \\
\text { Salafist Group for Preaching and Combat (GSPC) } \\
\text { Soldiers of the Caliphate } \\
\text { Timizart Brigade }\end{array}$ \\
\hline Burkina Faso & $\begin{array}{l}\text { Al-Qaeda in the Islamic Maghreb (AQIM) } \\
\text { Al-Mourabitoun (The Sentinels) } \\
\text { Ansaroul Islam } \\
\text { Islamic State (Sahara) }\end{array}$ \\
\hline Chad & $\begin{array}{l}\text { Alliance nationale de la résistance (ANR) } \\
\text { Alliance nationale démocratique (AND) } \\
\text { Armed Forces for a Federal Republic (FARF) } \\
\text { Boko Haram } \\
\text { Conseil national de redressement du Tchad (CNRT) } \\
\text { Conseil national de la résistance (CNR) } \\
\text { Conseil du sursaut national pour la paix et la démocratie (CSNPD) } \\
\text { Chadian National Concord (CNT) } \\
\text { Democratic Front for Renewal (FDR) } \\
\text { Forces des organisations nationales pour l'alternance et les libertés (FONALT) } \\
\text { Force pour le ratissage, le regroupement et le redressement du Tchad (FRRRT) } \\
\text { Front national tchadien rénové (FNTR) } \\
\text { Front patriotique de résistance (FPR) } \\
\text { Front populaire pour la renaissance nationale (FPRN) } \\
\text { Group of } 8 \text { December } \\
\text { Islamic Legion } \\
\text { Islamic State (Sahara) } \\
\text { Janjaweed } \\
\text { Movement for Democracy and Development (MDD) } \\
\text { Movement for Democracy and Justice in Chad (MDJT) } \\
\text { National Liberation Front of Chad (FROLINAT) } \\
\text { Patriotic Salvation Movement (MPS) } \\
\text { Platform for Change, Unity and Democracy (SCUD) } \\
\text { Popular Rally for Justice (RPJ) } \\
\text { Rally of Democratic Forces (RAFD) } \\
\text { Rally for Democracy and Liberty (RDL) } \\
\text { Rassemblement des fils unis du Tchad pour le développement (RFUTD) } \\
\text { Union of Forces for Democracy and Development (UFDD) } \\
\text { Union of Resistance Forces (UFR) } \\
\text { United Front for Change (FUC) } \\
\text { United Front for (Democratic) Change (FUC, FUCD) }\end{array}$ \\
\hline
\end{tabular}




\begin{tabular}{|c|c|}
\hline Country & Armed group \\
\hline \multirow[t]{2}{*}{ Libya } & $\begin{array}{l}\text { Abu Salim Martyrs Brigade } \\
\text { Ajdabiya Revolutionaries Shura Council } \\
\text { Al-Farouk Brigade } \\
\text { Al Moulathamoun (Those Who Sign in Blood) } \\
\text { Al-Mourabitoun (The Sentinels) }\end{array}$ \\
\hline & $\begin{array}{l}\text { Al-Qaeda } \\
\text { Al-Qaeda in the Islamic Maghreb (AQIM) } \\
\text { Al Qaqa Brigade } \\
\text { Al-Kanni Brigade } \\
\text { Ansar al-Sharia } \\
\text { Barqa Youth Movement } \\
\text { Benghazi Defense Brigades } \\
\text { Brega Martyrs Brigade } \\
\text { February 17th Martyrs Brigade } \\
\text { Fighters of The Martyrs Brigade } \\
\text { Free Libya Martyrs Brigade } \\
\text { Harakat al-Shuhada'a al-Islamiyah (Movement of Islamic Martyrs) } \\
\text { Islamic Emirate of Barqa } \\
\text { Islamic State (Libya) } \\
\text { Jaysh al-Mujahidin } \\
\text { Libyan Islamic Fighting Group (LIFG) } \\
\text { Libya Dawn } \\
\text { Libya Shield } 1 \\
\text { Libyan Rebel Forces } \\
\text { National Transitional Council (NTC) } \\
\text { Rafallah al-Sahati Brigade } \\
\text { Shura Council of Benghazi Revolutionaries } \\
\text { Shura Council of Islamic Youth }\end{array}$ \\
\hline Mali & $\begin{array}{l}\text { Al Moulathamoun (Those Who Sign in Blood) } \\
\text { Al-Mourabitoun (The Sentinels) } \\
\text { Al-Qaeda in the Islamic Maghreb (AQIM) } \\
\text { Ansar Dine } \\
\text { Ansar al Sharia (Mali) } \\
\text { Arab Islamic Front of Azawad (FIAA) } \\
\text { Arab Movement of Azawad (MAA) } \\
\text { Coalition for the People of Azawad (CPA) } \\
\text { Congrès pour la justice dans l'Azawad (CJA) } \\
\text { Coordination des mouvements de l'Azawad (CMA) } \\
\text { High Council for the Unity of Azawad (HCUA) } \\
\text { Jama'a Nusrat ul-Islam wa al-Muslimin' (JNIM) } \\
\text { Macina Liberation Front (FLM) } \\
\text { May 23, 2006 Democratic Alliance for Change (ADC) } \\
\text { Mouvement populaire de l'Azawad (MPA) } \\
\text { Mouvement pour le salut de l'Azawad (MSA) } \\
\text { Movement for Oneness and Jihad in West Africa (MUJAO) } \\
\text { North Mali Tuareg Alliance for Change (ATNMC) } \\
\text { Salafist Group for Preaching and Combat (GSPC) }\end{array}$ \\
\hline Mauritania & $\begin{array}{l}\text { Al-Qaeda in the Islamic Maghreb (AQIM) } \\
\text { Salafist Group for Preaching and Combat (GSPC) }\end{array}$ \\
\hline Morocco & $\begin{array}{l}\text { Al-Qaeda in the Islamic Maghreb (AQIM) } \\
\text { Moroccan Islamic Combatant Group (GICM) } \\
\text { Salafia Jihadia }\end{array}$ \\
\hline
\end{tabular}




\begin{tabular}{|l|l|}
\hline Country & Armed group \\
\hline Niger & Air and Azawad Liberation Front (FLAA) \\
& Armed Co-ordination Resistance (CRA) \\
& Al-Qaeda in the Islamic Maghreb (AQIM) \\
& Boko Haram \\
& Democratic Front for Renewal (FDR) \\
& Nigerien Movement for Justice (MNJ) \\
& Revolutionary Armed Forces of the Sahara (FARS) \\
& Salafist Group for Preaching and Combat (GSPC) \\
\hline Nigeria & Ansaru \\
(North-East) & Boko Haram \\
\hline Tunisia & Al-Qaeda in the Islamic Maghreb (AQIM) \\
& Ansar al Sharia (Tunisia) \\
& Tunisian Combatant Group (GCT) \\
\hline
\end{tabular}

Sources: Williams 2011, Chivvis 2016, United States Department of State, National Consortium for the Study of Terrorism and Responses to Terrorism (START), Global Terror Watch, ACLED 2016 and research by the author. Note: Ethnic and communal militias, and unidentified groups are not included. 



\section{ALSO IN THE WEST AFRICAN PAPERS SERIES:}

Allen, T. and P. Heinrigs (2016), "Emerging Opportunities in the West African Food Economy", West African Papers, No. 1, OECD Publishing, Paris. http://dx.doi.org/10.1787/5jlvfj4968jb-en

Lewis, K. and C. Buontempo (2016), “Climate Impacts in the Sahel and West Africa: The Role of Climate Science in Policy Making”, West African Papers, No. 2, OECD Publishing, Paris. http://dx.doi.org/10.1787/5jlsmktwjcd0-en

Gnisci, D. (2016), “Women's Roles in the West African Food System: Implications and Prospects for Food Security and Resilience", West African Papers, No. 3, OECD Publishing, Paris. http://dx.doi.org/10.1787/5jlpl4mh1hxn-en

Staatz, J. and F. Hollinger (2016), “West African Food Systems and Changing Consumer Demands", West African Papers, No. 4, OECD Publishing, Paris. http://dx.doi.org/10.1787/b165522b-en

Prieto Curiel, R., P. Heinrigs and I. Heo (2017), "Cities and Spatial Interactions in West Africa: A Clustering Analysis of the Local Interactions of Urban Agglomerations", West African Papers, No.5, OECD Publishing, Paris. http://dx.doi.org/10.1787/57b30601-en

Walther, O. (2017), “Cross-border Co-operation Networks in West Africa”, West African Papers, No. 06, OECD Publishing, Paris. http://dx.doi.org/10.1787/73298292-en

Ibrahim, I.Y. (2017), “The Wave of Jihadist Insurgency in West Africa: Global Ideology, Local Context, Individual Motivations", West African Papers, No. 07, OECD Publishing, Paris. http://dx.doi.org/10.1787/eb95c0a9-en

Allen, T. (2017), “The cost of high food prices in West Africa”, West African Papers, No. 08, OECD Publishing, Paris. http://dx.doi.org/10.1787/c2db143f-en

Van Den Hoek, J. (2017), “Agricultural market activity and Boko Haram attacks in northeastern Nigeria", West African Papers, N09, OECD Publishing, Paris. http://dx.doi.org/10.1787/13ba9f2e-en

For more information on the series, please contact: lia.beyeler@oecd.org 